\title{
THE STELA OF HEPU FROM THE LATE MIDDLE KINGDOM (GEM 23753/ JE 41638)
}

\author{
Tamer Mohammed FAWZI \\ Faculty of Arts, Menoufia Univ., Shebin El-Kom, Menoufia Governorate, Egypt \\ Email: tamer.mohammed86@art.menofia.edu.eg
}

\begin{abstract}
This paper aims to publish and study a roundtopped limestone stela belonging to Hpw. In good condition, it is kept at the Grand Egyptian Museum (GEM 23753). This paper tackles the offering formula terminology, the artistic style, and the spelling and palaeographic features. This stela is dated to the 13th Dynasty. The stela was made by a local artist as indicated by the rough outlines in areas of the stela.
\end{abstract}

\section{KEYWORDS}

Stela - Thirteenth Dynasty - hpw - El-Lisht

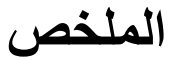

$$
\begin{aligned}
& \text { تهدف تللك المقالة إلى نشـــر ودر اســـة لوحة من الحجر }
\end{aligned}
$$

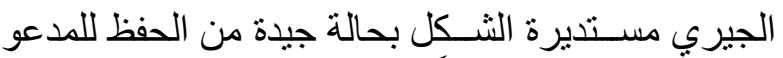

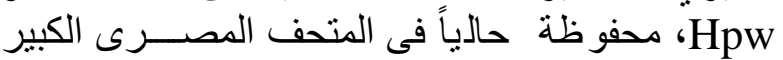

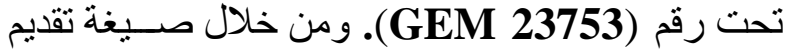

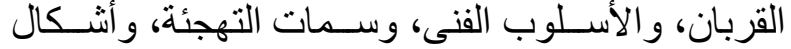

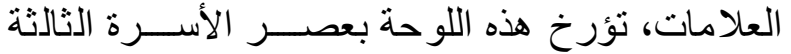

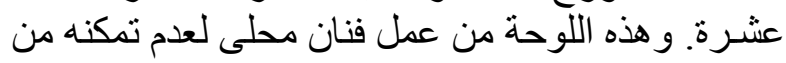

$$
\begin{aligned}
& \text { تنفيذ خطوطه فى بعض مو اضع اللوحة. } \\
& \text { الكلمات الدالة } \\
& \text { لوحة_ الأسرة الثالثة عشرة- hpw - اللثت. }
\end{aligned}
$$

\section{INTRODUCTION}

A stela kept at the Grand Egyptian Museum (inventory number GEM 23753), ${ }^{1}$ was excavated at el-Lisht by the expedition of the Metropolitan Museum of Art (1907-1908). This stela has not been fully published hitherto. ${ }^{2}$ It was found in the south chamber of pit 412, in Lisht North (Pyramid Temple of Amenemhat I). The same pit contained another stela of Hpw, which is now in the Lowe Art Museum, University of Miami (877509), ${ }^{3}$ and a superb royal head, possibly representing Amenemhat IV (New York, MMA 08.200.2). ${ }^{4}$

\section{DESCRIPTION}

It is a round-topped stela (Fig.1 and Pl. I). It is made of unpainted limestone and measures $44 \mathrm{~cm}$ in height, $31 \mathrm{~cm}$ in width and $7 \mathrm{~cm}$ in thickness. It is in good condition, though it is

\footnotetext{
${ }^{1}$ I am grateful to the authorities of the Grand Egyptian Museum for the permission to publish this stela and for providing good photographs. The stela previously held the inventory number of the Cairo Museum (JE 41638). ${ }^{2}$ This stela is noted by Gauthier, H., Le Livre des Rois d'Égypte. Recueil de tîtres et protocoles royaux, noms propres des rois, reines, princes et princesses, noms des pyramides et de temples solaires, suivi d'un index alphabétique.Vol.2, IFAO, (1912), 130 (25); PM, IV, 85; Bourriau, J., 'The contribution of the excavation of Lisht North Cemetery to Middle Kingdom Studies,' in: S. Quirke(ed.), Discovering Egypt from the Neva: The Egyptological Legacy of Oleg D. Berlev, Berlin, (2009), 56; Stefanović, D., 'Varia Epigraphica II: The Middle Kingdom', GM 244, (2015), 118, n.33.

${ }^{3}$ Stefanović, D., GM 244, (2015), 118-119, pl. IX.

${ }^{4}$ Bourriau, J., 'The contribution of the excavation of Lisht North', 56; Stefanović, GM 244, (2015), 118-119, 26.
} 
eroded at the bottom, and there is a crack running from the right side to the left of the stela. The back of the stela was left rough, suggesting that it was meant to be placed in a niche. The front surface was carefully cut and smoothed. The stela is executed in the silhouette style: the inscriptions and the images are cut in raised relief without further inner details. This style was popular in the Middle Kingdom, especially during the $13^{\text {th }}$ Dynasty, ${ }^{1}$ though it was already known at the beginning of the $12^{\text {th }}$ Dynasty. ${ }^{2}$

The stela is divided into two registers: the upper register is framed by incised borders lines. It contains the main scene of the stela. It shows the seated owner facing right; there is no offering table in front of him. He sits on a chair with a high backrest and lion legs on short drums. His features and some details of the body are somewhat obscured. He wears a calflength kilt reaching the ankles. The remains of a kilt-knot appear on the waist. His left arm holds a long staff that rests on the ground. His clenched right hand rests on his right thigh. In front of him, two vertical lines of a hieroglyphic inscription are engraved and divided by two vertical incised lines. The lower register shows the main inscription of three horizontal lines of text with borderlines.

\section{INSCRIPTION}

\subsection{The upper register}

The inscription reads from left to right. It contains an offering formula:

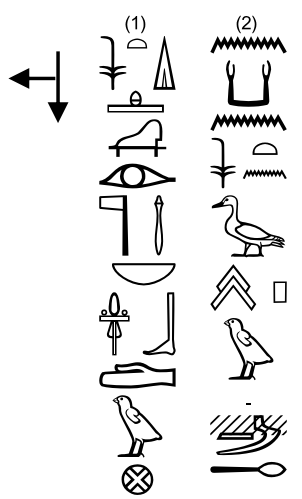

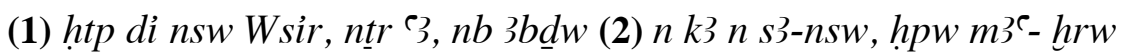

(1) An offering-that-the-king-gives of ${ }^{(\mathbf{a})}$ Osiris ${ }^{(\mathbf{b})}$, the great $\operatorname{god}^{(\mathbf{c})}$, lord of Abydos. ${ }^{(\mathbf{d})}$

(2) for the ka of ${ }^{(\mathbf{e})}$ the king's son ${ }^{(\mathbf{f})} \mathrm{Hepu},{ }^{(\mathbf{g})}$ justified.

\footnotetext{
${ }^{1}$ Franke, D., Das Heiligtum des Heqaib auf Elephantine: Geschichte eines Provinzheiligtums im Mittleren Reich. Studien zur Archäologie und Geschichte Altägyptens 9, Heidelberg, (1994), 115; Grajetzki, W., Two Treasurers of the Late Middle Kingdom, London, (2001), 62-63; Bishoff, A \& Grajetzki, W., 'A stela of the Early Middle Kingdom in the South African Cultural History Museum', DE 54, (2002), 37; Ilin-Tomich, A., From Workshop to Sanctuary: The Production of Late Middle Kingdom Memorial Stelae. Middle Kingdom Studies 6, London, (2017), 75, 78.

${ }^{2}$ The earliest example of silhouette style stelae is the stela Berlin 1192 dating to the reign of Senwosret I. They frequently occur from the end of the $12^{\text {th }}$ Dynasty and during the $13^{\text {th }}$ Dynasty. Simpson, W.K., The Terrace of the Great God at Abydos: The Offering Chapels of Dynasties 12 and 13, New Haven, (1974), 19, pl. 49 (ANOC 31.2); Freed, R.E., 'Stela Workshops of Early Dynasty 12', in: Studies in Honor of William Kelly Simpson, I. ed.P. Der Manuelian, Boston, (1996), 318, fig. 7b; Lebedev, M.A., 'Stela Nubia Museum 59485: the last known expedition of the early Middle Kingdom beyond the Nile Valley’, Вопросы эпиграфики. Вып. VII. Ч. 1: Материалы I Международной конференции «Вопросы эпиграфики». М., (2013), 209-210; Ilin-Tomich, A., From Workshop to Sanctuary, 76-78.
} 


\subsection{The lower register}

Three horizontal lines of inscription run from right to left with borderlines and read:

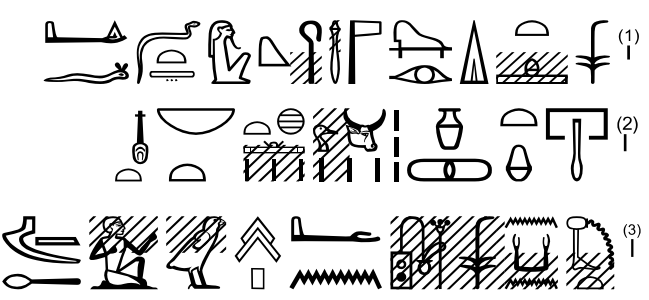

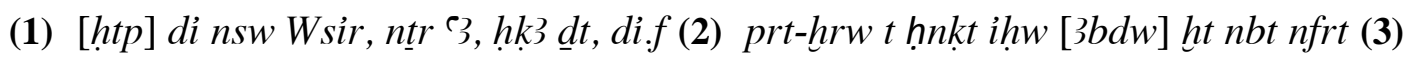
$w^{c} b[t] n[k 3 n]\left[s{ }^{\ulcorner}\right]^{`} n\left[n s w^{l}\right] h p w m 3^{c}-h r w$

(1) An [offering]-that-the-king-gives of Osiris ${ }^{2}$, the great god, ruler of eternity ${ }^{(\mathbf{h})}$ that he may give ${ }^{(\mathbf{i})}(\mathbf{2})$ an invocation-offering consisting of bread and beer ${ }^{(\mathbf{j})}$, oxen and [fowl] ${ }^{(\mathbf{k})}$, all good (3) and pure things ${ }^{(\mathbf{l})}$, for the [ka] of [the secretary] of documents of [the king ${ }^{(\mathbf{m})}$ ],

$$
\mathrm{Hepu}^{(\mathbf{n})} \text {, justified. }
$$

\section{COMMENTARY}

(a) The $h t p$-sign between $n s w$ and $d i \neq \stackrel{\theta}{*} \Delta$ is very commonly found on the monuments of the Middle Kingdom and was attested until the $13^{\text {th }}$ Dynasty. ${ }^{3}$

(b) The sign $九$ [Q2] has unusual writing. The use of the sign $\AA_{[Q 2]}$ in the name of Osiris is one of the features which were first used at the very end of the $12^{\text {th }}$ Dynasty and in the $13^{\text {th }}$ Dynasty $^{4}$. Ilin-Tomich has noted that the use of this sign $\bumpeq[\mathrm{Q} 2]$ instead of $[$ [Q1] in the name of Osiris was first attested under Amenemhat IV and its use continued during the $13^{\text {th }}$ Dynasty. ${ }^{5}$ Bennett also mentioned that the spelling of the god Osiris's name ${ }^{6}$ was changed

${ }^{1}$ Wb, III, 480,14; Hannig, R., Großes Handwörterbuch Ägyptisch-Deutsch. Die Sprache der Pharaonne, Mainz, (1995), 760.

${ }^{2}$ For this translation: Mekawy Ouda, A. M, 'The Statue of The Doorkeeper of the Palace Pi3y (Louvre E 124),' SAK 44, (2015), 283-295.

${ }^{3}$ Smither, P.C., 'The Writing of htp di nsw in the Middle and New Kingdoms,' JEA 25, (1939), 34 (table). See also: Barta, W., Aufbau und Bedeutung der altägyptischen Opferformel, ÄF 24, Gluckstadt, (1968), 43-84; Vernus, P., 'Sur les graphies de la formule 'l'offrande que donne le roi' au Moyen Empire et à la Deuxième Période Intermédiaire,' in: S. Quirke (ed.), Middle Kingdom Studies, New Malden, (1991), 144-145; Satzinger, H., 'Beobachtungen zur Opferformel: Theorie and Parxis,' LinAeg 5, (1997), 177-188; Franke, D., 'The Middle Kingdom Offering Formulas - A Challenge', JEA 89, (2003), 39-40; Ilin-Tomich, A., 'Changes in the $h t p-d i$ $n s w$ Formula in the Late Middle Kingdom and the Second Intermediate Period', Z̈̈S 138, (2011), 20-34; IlinTomich, A., From Workshop to Sanctuary, 14-17.

${ }^{4}$ Berlev cites the toilet box MMA 26.7.1438 (Amenemhat IV) as the earliest example of $\Omega$ in the name of Osiris. Another early example is cited by Ilin-Tomich on an offering table from the tomb of Neferuptah from the reign of Amenemhat IV or, less likely, Amenemhat III. Berlev, O.D \& Hodjash, S.I., Sculpture of Ancient Egypt in the Collection of the Pushkin State Museum of Fine Arts, Moscow, (2004), 115; Ilin-Tomich, A., ZÄS 138, (2011), 21, n. 13.

5Ilin-Tomich, A., Z̈̈S 138, (2011), 21. Franke pointed out that most attestations of the reverse sign $\Omega$ [Q2] date from the later part of the $13^{\text {th }}$ Dynasty and the subsequent period. Ilin-Tomich argues that his study of stelae confirms Franke's conclusion. Ilin-Tomich, A., From Workshop to Sanctuary, 8-9.

${ }^{6}$ For further information about the discussion regarding the spelling of the name of Osiris and determinatives that are attached to it: Erman, A., 'Zum Namen des Osiris,' Z̈̈S 46, (1909), 92-95; Bates, O., 'The Name of Osiris,' JEA 2, (1915), 207-208; Leahy, A., 'The Name of Osiris Written,' SAK 7, (1979), 141-53; Rosati, G., 'Note e proposte per la datazione delle stele del Medio Regno,' OrAnt 19, (1980), 269-278. 
during the Middle Kingdom. During the $11^{\text {th }}$ Dynasty, and often in the early $12^{\text {th }}$ Dynasty,

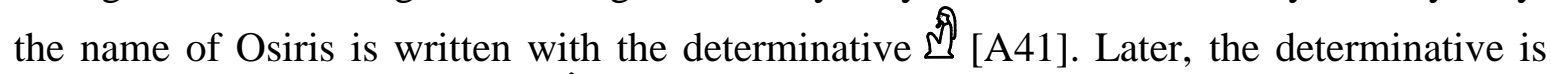
usually dropped. Instead of $\frac{\text { f }}{d}$ [A43] often appears during the $11^{\text {th }}$ Dynasty and early $12^{\text {th }}$ Dynasty. ${ }^{1}$

(c) On the stela the sign 8 [O29] has unusual writing. The epithet $7 \hat{8} n \underline{-}-r^{2}{ }^{2}$ was used as a title for Osiris from the reign of Senwosret I. ${ }^{3}$

(d) The word $3 b \underline{d} w$ was written with the sign ${ }^{\frac{0}{4}}$ [R15]. ${ }^{4}$ Otherwise, the writing of $3 b \underline{d} w$ with the palm and a hand-sign $\leftrightharpoons[\mathrm{D} 46]$ only occurs from the New Kingdom. ${ }^{5}$ According to IlinTomich, the only known exception is on stela Cairo JE 91243 from the reign of Amenemhat III. No written examples for $3 b \underline{d} w$ with the palm-sign are attested before the New Kingdom. ${ }^{6}$

Osiris with his epithets ( $n t r{ }^{9}{ }^{3} n b 3 b \underline{d} w$ ) is mostly seen during the $12^{\text {th }}$ and $13^{\text {th }}$ Dynasties. $^{7}$ His epithets are of interest chiefly because they changed in each period; during the $11^{\text {th }}$ Dynasty, they are usually $n b \underline{d} d w$, hnty imntyw, and $n b 3 b \underline{d} w$. In the reign of Senwosret I, the epithet ntr-?3 is added. Under Senwosret III all the god's epithets are usually dropped, except hnty-imntyw. ${ }^{8}$

(e) The sign of $\mathrm{kA}$ with ring-shaped hands $\mathrm{R} \rho$ is a common feature from the $13^{\text {th }}$ Dynasty and later. ${ }^{9}$ The text prefaces the name of the stela owner with $n k 3 n$ "for the ka of". The use of $n k 3 n$ NN at the end of the invocatory formula was already attested at the end of the $12^{\text {th }}$ Dynasty, rather than the formulation $n i m 3 h w N N$ or $n k 3 n i m 3 h w N N,{ }^{10}$ which stopped

\footnotetext{
${ }^{1}$ Bennett, C.J., 'Growth of the htp di nsw Formula in the Middle Kingdom', JEA 27, (1941), 80.

2 For $n t r-{ }^{3}$ referring to Osiris: Fischer, H.G., 'Marginalia II', GM 128, (1992), 72-5; Stefanović, D., 'Four Middle Kingdom stelae from the National Archaeological Museum, Athens', JEA 96, (2010), 209, n. 8.

${ }^{3}$ Bennett, C.J., JEA 27, (1941), 78.
}

${ }^{4}$ For the writing of the place name Abydos with the $\frac{00^{\frac{9}{4}}}{i 3 b}$ sign: Gardiner, A.H., Egyptian Grammar, Oxford, (1964), 502; Franke, D., 'The Late Middle Kingdom (Thirteenth to Seventeenth Dynasties): The Chronological Framework,' JEH 1.2, (2008), 280, n.48. According to Gardiner, from the Eighteenth Dynasty, confusion with the sign? [U23]. El-Sayed, R., 'Documents relatifs à Sais et ses divinités', BdE XLIX, Cairo, (1975), 151 (i). Early examples are, e.g., Urk. IV 11[49]; Bosticco, S., Museo Archeologico di Firenze. Le Stele egiziane del nuovo regno, Rome, (1965), no.4 (2496), 6 (2508), 13 (6387); Satzinger, H\& Stefanović, D. 'The Stela of Horemhat at Turin', $C d E$ LXXXIV, (2009), 91.

5Ilin-Tomich, A., 'Two Notes on Middle Kingdom Annals', LinAeg 18, (2010), 125.

${ }^{6}$ Simpson, W.K., Inscribed Material from the Pennsylvania-Yale Excavations at Abydos, PPYEE 6, New Haven-Philadelphia, (1995), 36-35, fig. 61, pl. 7; Gomaà, F., Die Besiedlung Ägyptens während des Mittleren Reiches, Beihefte zum, I. Oberägypten und des Fayyum. Tübinger Atlas des Vorderen Orients.Reihe B (Geisteswissenschaften) 66, Wiesbaden, (1986), 198; Ilin-Tomich, A., LinAeg 18, (2010), 125, n. 48.

${ }^{7}$ Selim, H.,'Three identical stelae from the end of the Twelfth or Thirteenth Dynasty,'in: SAK 29, (2001), 325. ${ }^{8}$ Bennett, C.J., JEA 27, (1941), 78, 80; Franke, D., 'The Good Shepherd Antef (Stela BM EA 1628),' JEA 93, (2007), 170-171, n.87.

${ }^{9}$ Grajetzki, W., Two Treasurers of the Late Middle Kingdom, 69 [Hannover 2932, Leiden 31, Vienna ÄS 135, 163, 181]; Marée, M., 'Edfu under the Twelfth to Seventeenth Dynasties: The Monuments in the National Museum of Warsaw,' BMSAES 12, (2009),43-50, fig. 7 [Warsaw 141262: cf. fg. 8a-b], 47-48, fig. 9 [Tübingen 463], 50, fig. 10; Ilin-Tomich, A., 'Late Middle Kingdom Stelae Workshops at Thebes,' GM 234, (2012), 80; Mekawy Ouda, A. M., 'Egyptian Middle Kingdom Oyster Shells with Royal Names Function, Chronology and Gender Issues,' BIFAO 119, (2019), 267; Mekawy Ouda, A. M., 'Two Inscribed Middle Kingdom Oyster Shells from Esna: Reconstructing Their Archaeological Context', $C d E$ (2019), 55.

${ }^{10}$ The phrase $n k 3$ im $3 h w N N$ "for ka of the favoured NN" was common during the $12^{\text {th }}$ Dynasty, but disappeared after that. Ilin-Tomich, A., From Workshop to Sanctuary, 31. 
occurring after the reign of Amenemhat II. ${ }^{1}$ Furthermore, all the inscriptions dated to the $13^{\text {th }}$ Dynasty use the form $n k 3 n$ NN to introduce the recipient. ${ }^{2}$

(f) The stela identifies Hepu as a $s 3-n s w .^{3}$ This title was held by non-royal individuals in the $13^{\text {th }}$ Dynasty and the Second Intermediate Period, when many principalities existed side by side. Each claimed royal prerogatives and titles for their ruling families. For example, the owner of the stela Cairo CG 20537 held the title "royal son", while being the son of a "count and overseer of the priests". ${ }^{4}$ Nevertheless, Hepu's second stela LAM 877509 also features his mother Abeteni. She has the title hmt-nswt and is depicted wearing a crown with two tall plumes, ${ }^{5}$ suggesting that their family had claimed some level of local rulership.

(g) hpw: Ranke mentioned that this name was attested on the monuments of the Old, Middle and New Kingdom, mainly as a masculine name, but also occasionally as a feminine name. ${ }^{6}$ This name was incised on a Middle Kingdom funerary stela e.g., stela Athens $4054 \mathrm{a} ;{ }^{7}$ Cairo CG 20123; CG 20409; CG 20675. ${ }^{8}$ Remarkably, there is a space after the name of $h p w . ~ I$ suggests that it was left for the determinative of the sitting man [A1], a common feature used to refer to personal names, which is written in the third line of the lower register.

(h) The epithet $h k 3-d t$ "ruler of eternity"9 as an epithet of Osiris is attested no earlier than the $13^{\text {th }}$ Dynasty. ${ }^{10}$ For examples, see: Stela Berlin $7311 ;{ }^{11}$ Cairo CG 20039; CG 20050; CG 20614. ${ }^{12}$

(i) The attestation of di.f after the formula htp di $n s w$ and before prt-hrw indicates the $12^{\text {th }}$ Dynasty or later. According to Bennett, ${ }^{13}$ the term prt-hrw "an invocation" is in offering formulas of the $11^{\text {th }}$ Dynasty, whereas in the $12^{\text {th }}$ Dynasty, the formula di.f prt-hrw "that he may give an invocation" is preferred. Obsomer also emphasises the importance of di.f prt-

\footnotetext{
${ }^{1}$ Bennett, C.J., JEA 27, (1941), 79 (6); Pflüger, K., 'The Private Funerary Stelae of the Middle Kingdom and their importance for the study of Ancient Egyptian History,' JAOS 67, (1947), 133.

${ }^{2}$ Ilin-Tomich, A., ZÄS 138, (2011), 26.

${ }^{3}$ Ward, W., Index of Egyptian Administrative and Religious Titles of the Middle Kingdom: with a Glossary of words and Phrases Used, Beirut, (1982), 145, no.1245.

${ }^{4}$ Frankfort, H., 'The Cemeteries of Abydos: Work of the Season 1925-26,' JEA 14, (1928), 238.

- For further information and references about the title s3-nsw: Schmitz, B., Untersuchungen zum Titel s3-nsw "Königssohn", Bonn, (1976), 186-190; 228-244; Quirke, S., 'Identifying the Officials of the Fifteenth Dynasty', in M. Bietak, E. Czerny (eds.), Scarabs of the Second Millennium BC from Egypt, Nubia, Crete and the Levant: Chronological and Historical Implications. Papers of a Symposium, Vienna, 10th-13th of January 2002, Wien, (2004), 171-193.

${ }^{5}$ Stefanović, D., GM 244, (2015), 119,126, pl. IX.

${ }^{6}$ Ranke, $P N$ I, 238.14.

${ }^{7}$ Ilin-Tomich, A., From Workshop to Sanctuary, pl. 16 (left).

${ }^{8}$ Lange, H.O \& H. Schäfer, H., Grab und Denksteine des Mitteren Reich im Museum von Kairo, Vol. I, 145146; Vol. II, 9-11, 301-302.

${ }^{9}$ For the epithet, see $L A G G \mathrm{~V}, 531-532$.

${ }^{10}$ Spiegel, J., Die Götter von Abydos; Studien zum ägyptischen Synkretismus, Wiesbaden, (1973), $174 ;$ G. Rosati, G., OrAnt 19 (1980), 274; Ilin-Tomich, A., ZÄS 138, (2011), 21; Id., From Workshop to Sanctuary, 27. ${ }^{11}$ Simpson, W.K., The Terrace of the Great God at Abydos, pl. 32, ANOC 22.

${ }^{12}$ Lange, H.O \& Schäfer, H., Grab und Denksteine des Mitteren Reich im Museum von Kairo, Vol. I, 48-49, 59-60; Vol. II, 253-255.

${ }^{13}$ Bennett, C.J., JEA 27, (1941), 77-78.
} 
hrw as a dating criterion, arguing that it was not attested in offering formulas before the $12^{\text {th }}$ Dynasty. ${ }^{1}$

(j) An unusual writing of the hnkt-sign ₹्ञ. Ilin-Tomich pointed out that the spelling of the word Hnkt "beer" in the offering formula with the sign having two crossing lines, can be classified as [W20] or [W59], first occur in the Thirteenth Dynasty

And become widespread in the Second Intermediate Period. ${ }^{2}$

(k) The writing of 1 I I $i h w$ - $3 b d w$ "oxen and fowl" occurs occasionally in the late $12^{\text {th }}$ Dynasty and becomes common during the $13^{\text {th }}$ Dynasty and the Second Intermediate Period ${ }^{3}$.

(l) The word $\frac{1}{\mathrm{I} 1 \mathrm{I}} h t$ "things" is written with the determinative w1]. This writing occurs occasionally in the $13^{\text {th }}$ Dynasty and becomes common in the Second Intermediate Period. ${ }^{4}$

(m) Most of the first half of the third line is destroyed, whereas only a few traces remain of some hieroglyphic signs [N35] and the two top ends of the sign $\mathrm{is}$. These traces could be completed as follows: $\stackrel{\square}{4}$. After this part, the owner's name and titles would typically follow, as in the second line of the upper register. The title of $h p w$ is gone except the word

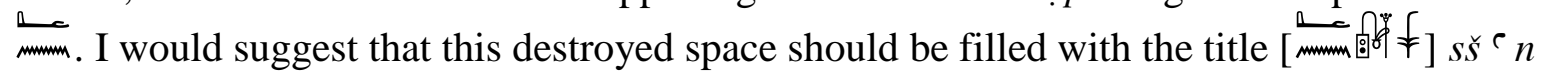
$n s w t$ "the secretary of documents of the king", 5 compared to a similar text which was found on the second stelae of Hpw LAM 877509. ${ }^{6}$ Quirke mentioned that this title is known in the early Middle Kingdom. In contrast in the late Middle Kingdom, most sources are more specific, differentiating between the person present at court with the king and those with responsibility for "assembly" and "lands". ${ }^{7}$ In Hepu's second stela, his full title is given as $s \check{s}$ $n n s w t n s m 3 y t$ "the secretary of the documents of the king of the assembly".

(n) Notice that the determinative sign [A1] was written in cursive hieroglyphs. ${ }^{8}$ The use of determinatives with cursive hieroglyphs after the individuals' names was common in the late $12^{\text {th }}$ and $13^{\text {th }}$ Dynasties. For examples, see: (JE 52453 $\left.{ }^{9}\right)$; (JE 20458 $\left.{ }^{10}\right)$; (JE 91244); (JE 91249) $)^{11}$; (BM EA 220); (BM EA 226 ${ }^{12}$ ). According to Ilin-Tomich, in the Middle Kingdom,

\footnotetext{
${ }^{1}$ Obsomer, C., 'di.f prt hrw et la filiation $m s(t) . n / \operatorname{ir}(t) . n$ comme critères de datation dans les textes du Moyen Empire,' in: Ch. Cannuyer, J.-M. Kruchten (eds.), Individu, société et spiritualité dans l'Égypte pharaonique et copte: Mélanges égyptologiques offerts au Professeur Aristide Théodorides, Brussels, (1993), 169-170, 196197. See also: Satzinger, H., LinAeg 5, (1997), 177-188; Selim, H., SAK 29, (2001), 325-326; Metawi, R., 'The Stela of the Chief Interior-Overseer to the Treasurer Hrw-nfr (Cairo Museum CG 20563) , JARCE 44, (2008), 148.

${ }^{2}$ Cf. Ilin-Tomich, A., From Workshop to Sanctuary, 20, (Table 11).

3Ilin-Tomich, A., Z̈̈S 138, (2011), 24-25, (Table 2); Id., From Workshop to Sanctuary, 20-21, (Table 12).

${ }^{4}$ Ilin-Tomich, A., From Workshop to Sanctuary, 22-23, (Table 14).

${ }^{5}$ Wb, I, 158,20; Ward, W., Index of Egyptian Administrative and Religious Titles, 158, no.1363; Quirke, S., Titles and bureaux of Egypt 1850-1700 BC, London, (2004), 43.

${ }^{6}$ Stefanović, D., GM 244, (2015), 119,126, pl. IX.

${ }^{7}$ For further information and references about this title: Quirke, S., Titles and bureaux, 42-44.

${ }^{8}$ The palaeography of cursive hieroglyphic script is common from the $12^{\text {th }}$ Dynasty and later. Caminos, R. \& Fischer, H.G., Ancient Egyptian epigraphy and paleography, New York, (1976), 42-43.

${ }^{9}$ Davies, W.V., 'The tomb of a Governor of Elkab of the Second Intermediate Period.' In The World of Middle Kingdom Egypt (2000-1550 BC), Middle Kingdom Studies 2, London, (2016), 80 fig.10.

${ }^{10}$ Simpson, W.K., The Terrace of the Great God at Abydos, pl. 36, ANOC 24.

${ }^{11}$ Simpson, W.K., Inscribed Material from the Pennsylvania-Yale Excavations at Abydos, 40-41, figs. 66, 69.

${ }^{12}$ Budge, W., Hieroglyphic Texts from Egyptian Stelae in the British Museum, III, pl.3; IV, pl. 43.
} 
the determinatives for the seated men or women are not used after names. Only a limited number of examples are derived from the $12^{\text {th }}$ and $13^{\text {th }}$ Dynasties. On the other hand, during the Second Intermediate Period, this usage became increasingly common. ${ }^{1}$

\section{CONCLUSION}

The stela does not contain a royal name or dateline. However, the approximate date of this stela, based on its artistic style, the palaeographic features and orthographic criteria mentioned above, is the $13^{\text {th }}$ Dynasty. The $13^{\text {th }}$ Dynasty artistic style may be further corroborated by the relatively poor quality of the depictions and hieroglyphs executed in the so-called silhouette style. This technique was prevalent in the late Middle Kingdom, especially in the $13^{\text {th }}$ Dynasty. Furthermore, the silhouette style was characteristic of craftsmen from the Memphite and Fayum regions. ${ }^{2}$ Linguistic evidence points to the $13^{\text {th }}$ Dynasty, such as the use of the sign $\bumpeq$ [Q2] in the divine name of Osiris and his title "ruler of eternity". Both indicate a date, not before the $13^{\text {th }}$ Dynasty. ${ }^{3}$ On the other hand, according to Vernus, the stela's date must not be later than the $13^{\text {th }}$ Dynasty due to the order of the offering formula. ${ }^{4}$ The writing of the word $h n k t$ "beer" with a sign having two crossing lines and the word ht "thing" was written with the abstract determinative [Y1] in the offering formula in the $13^{\text {th }}$ Dynasty and became common in the Second Intermediate Period. All these criteria point to a $13^{\text {th }}$ Dynasty date or later.

${ }^{1}$ For further information: Ilin-Tomich, A., From Workshop to Sanctuary, 23-24.

${ }^{2}$ Grajetzki, W., Two Treasurers of the Late Middle Kingdom, 62; Ilin-Tomich, A., From Workshop to Sanctuary, 76-78.

${ }^{3}$ Ilin-Tomich, A., From Workshop to Sanctuary, 8, 27.

${ }^{4}$ Vernus, P., Sur les graphies de la formule 'l'offrande que donne le roi', 151-152; EL-Sayed, M., "Late Middle Kingdom Stelae from Assiut', in Fischer-Elfert, H. W., \& Parkinson, R. B., (eds.), Studies on the Middle Kingdom in Memory of Detlef Franke, Philippika 41, Wiesbaden, (2013),166. 


\section{BIBLIOGRAPHY}

1- Barta, W., Aufbau und Bedeutung der altägyptischen Opferformel, ÄF 24, Gluckstadt, (1968).

2- Bates, O., 'The Name of Osiris', JEA 2, (1915), 207-208.

- Bennett, C.J., 'Growth of the htp di nsw Formula in the Middle Kingdom', JEA 27, (1941), 77-82.

3- Berlev, O.D \& Hodjash, S.I., Sculpture of Ancient Egypt in the Collection of the Pushkin State Museum of Fine Arts, Moscow, (2004).

4- Bishoff, A \& Grajetzki, W., 'A stela of the Early Middle Kingdom in the South African Cultural History Museum', in: DE 54, (2002), 35-38.

5- Bosticco, S., Museo Archeologico di Firenze. Le Stele egiziane del nuovo regno, Rome, (1965).

6- Budge, W., Hieroglyphic Texts from Egyptian Stelae in the British Museum, III, London, (1912).

7- Budge, W., Hieroglyphic Texts from Egyptian Stelae in the British Museum, IV, London, (1913).

8- Bourriau, J., 'The contribution of the excavation of Lisht North Cemetery to Middle Kingdom Studies', in: Discovering Egypt from the Neva: The Egyptological Legacy of Oleg D. Berlev, ed. By S. Quirke, Berlin, (2003), 51-59.

9- Caminos, R. \& Fischer, H.G., Ancient Egyptian epigraphy and paleography, New York, (1976).

10- Davies, W.V., The tomb of a Governor of Elkab of the Second Intermediate Period. 'In The World of Middle Kingdom Egypt (2000-1550 BC), Middle Kingdom Studies 2, London, (2016).

11- EL-Sayed, M., 'Late Middle Kingdom Stelae from Assiut', in Fischer-Elfert, H. W., \& Parkinson, R. B.,(eds.), Studies on the Middle Kingdom in Memory of Detlef Franke, Philippika 41, Wiesbaden, (2013),161-199.

12- El-Sayed, R., 'Documents relatifs à Sais et ses divinités', BdE XLIX, Le Caire, (1975).

13- Erman, A., 'Zum Namen des Osiris', ZÄS 46, (1909), 92-95.

14- Fischer, H.G., 'Marginalia II', GM 128, (1992), 72-5.

15- Franke, D., Das Heiligtum des Heqaib auf Elephantine: Geschichte eines Provinzheiligtums im Mittleren Reich. Studien zur Archäologie und Geschichte Altägyptens 9, Heidelberg, (1994).

16- Franke, D., 'The Middle Kingdom Offering Formulas-A Challenge', JEA 89, (2003), 3957.

17- Franke, D., 'The Good Shepherd Antef (Stela BM EA 1628)', JEA 93, (2007), 149-174.

18- Franke, D., 'The Late Middle Kingdom (Thirteenth to Seventeenth Dynasties): The Chronological Framework', JEH 1.2, (2008), 267-287.

19- Frankfort, H., 'The Cemeteries of Abydos: Work of the Season 1925-26', JEA 14, (1928), 235-245.

20- Freed, R.E., 'Stela Workshops of Early Dynasty 12', in: Studies in Honor of William

Kelly Simpson, I, ed.P. Der Manuelian, Boston, (1996), 297-336.

21- Gardiner, A.H., Egyptian Grammar, Oxford, (1964).

22- Gauthier, H., Le Livre des Rois d'Égypte. Recueil de tîtres et protocoles royaux, noms propres des rois, reines, princes et princesses, noms des pyramides et de temples solaires, suivi d'un index alphabétique.Vol.2, IFAO, (1912).

- 93 - DOI: 10.21608/shedet.2021.207781 
23- Gomaà, F., Die Besiedlung Ägyptens während des Mittleren Reiches, Beihefte zum, I.Oberägypten und des Fayyum. Tübinger Atlas des Vorderen Orients.Reihe B (Geisteswissenschaften) 66, Wiesbaden, (1986).

24- Grajetzki, W., Two Treasurers of the Late Middle Kingdom, London, (2001).

25-Hannig, R., Großes Handwörterbuch Ägyptisch-Deutsch.Die Sprache der Pharaonne, Mainz, (1995).

26- Lange, H.O \& Schäfer, H., Grab und Denksteine des Mitteren Reich im Museum von Kairo Nos. 20001-20780, Catalogue Général des Antiquités Égyptiennes du Musée du Caire, I, Texte zu N $\mathrm{N}^{\mathrm{os}}$. 20001-20399, Berlin, (1902).

27- Lange, H.O \& Schäfer, H., Grab und Denksteine des Mitteren Reich im Museum von Kairo $\mathrm{N}^{\mathrm{os}}$. 20001-20780, Catalogue Général des Antiquités Égyptiennes du Musée du Caire, II, Texte zu Nos. 20400-20780, Berlin, (1908).

28-Lebedev, M.A., 'Stela Nubia Museum 59485: the last known expedition of the early Middle Kingdom beyond the Nile Valley', Вопросы эпиграфики. Вып. VII. Ч. 1: Материалы I Международной конференции «Вопросы эпиграфики». М., (2013), 207226.

29- Ilin-Tomich, A., 'Two Notes on Middle Kingdom Annals', LinAeg 18, (2010), 119-129. 30- Ilin-Tomich, A., 'Changes in the Htp-di-nsw Formula in the Late Middle Kingdom and the Second Intermediate Period', ZÄS 138, (2011), 20-34.

31-Ilin-Tomich, A., 'Late Middle Kingdom Stelae Workshops at Thebes', GM 234, (2012), 69-84

32-Ilin-Tomich, A., From Workshop to Sanctuary: The Production of Late Middle Kingdom Memorial Stelae. Middle Kingdom Studies 6, London, (2017).

33- Marée, M.,' Edfu under the Twelfth to Seventeenth Dynasties: The Monuments in the National Museum of Warsaw', BMSAES 12, (2009), 31-92.

34- Mekawy Ouda, A. M, 'The Statue of the Doorkeeper of the Palace PiAy (Louvre E 124)', SAK 44, (2015), 283-295.

35- Mekawy Ouda, M. A., 'Egyptian Middle Kingdom Oyster Shells with Royal Names Function, Chronology and Gender Issues', BIFAO 119, (2019), 259-272.

36- Mekawy Ouda, A. M.,' Two Inscribed Middle Kingdom Oyster Shells from Esna: Reconstructing Their Archaeological Context', Chronique d'Égypte (2019), 49-58.

37- Metawi, R. 'The Stela of the Chief Interior-Overseer to the Treasurer Hrw-nfr (Cairo Museum CG 20563)', JARCE 44, (2008), 141-151.

38-Obsomer, C., 'di.f prt hrw et la filiation $m s(t) . n / \operatorname{ir}(t) . n$ comme critères de datation dans les textes du Moyen Empire', in Ch. Cannuyer, J.-M. Kruchten (eds), Individu, société et spiritualité dans l'Égypte pharaonique et copte: Mélanges égyptologiques offerts au Professeur Aristide Théodorides, Brussels, (1993), 163- 201.

39- Pflüger, K., 'The Private Funerary Stelae of the Middle Kingdom and their importance for the study of Ancient Egyptian History', JAOS 67, (1947), 127-135.

40- Quirke, S., Titles and bureaux of Egypt 1850-1700 BC, London, (2004).

41- Quirke, S., 'Identifying the Officials of the Fifteenth Dynasty', in M. Bietak, E. Czerny (eds.), Scarabs of the Second Millennium BC from Egypt, Nubia, Crete and the Levant: Chronological and Historical Implications. Papers of a Symposium, Vienna, 10th-13th of January 2002, Wien, (2004), 171-193.

42- Rosati, G., 'Note e proposte per la datazione delle stele del Medio Regno', OrAnt 19 (1980), 269-278.

43- Satzinger, H., 'Beobachtungen zur Opferformel: Theorie and Parxis', LinAeg 5, (1997), 177-188. 
44- Satzinger, H\& Stefanović, D. 'The Stela of Horemhat at Turin', Chronique d'Égypte LXXXIV, (2009), 88-98.

45- Schmitz, B., Untersuchungen zum Titel s3-nsw "Königssohn", Bonn, (1976).

46- Selim, H. 'Three identical stelae from the end of the Twelfth or Thirteenth Dynasty', SAK 29, (2001), 319-330.

47- Simpson, W.K., The Terrace of the Great God at Abydos: The Offering Chapels of Dynasties 12 and 13, New Haven, (1974).

48- Simpson, W.K., Inscribed Material from the Pennsylvania-Yale Excavations at Abydos, PPYEE 6, New Haven-Philadelphia, (1995).

49- Smither, P.C., 'The Writing of Htp di nsw in the Middle and New Kingdoms', JEA 25, (1939), 34-37.

50- Spiegel, J., Die Götter von Abydos; Studien zum ägyptischen Synkretismus, Wiesbaden, (1973).

51- Stefanović, D., 'Four Middle Kingdom stela from the National Archaeological Museum, Athens', JEA 96, (2010), 207-2015.

52- Stefanović, D., 'Varia Epigraphica II: The Middle Kingdom', GM 244, (2015), 113-126. 53- Vernus, P., 'Sur les graphies de la formule 'l'offrande que donne le roi' au Moyen Empire et à la Deuxième Période Intermédiaire', in: S. Quirke (ed.), Middle Kingdom Studies, New Malden, (1991), 141-152.

54- Ward, W., Index of Egyptian Administrative and Religious Titles of the Middle Kingdom: with a Glossary of words and Phrases Used, Beirut, (1982). 


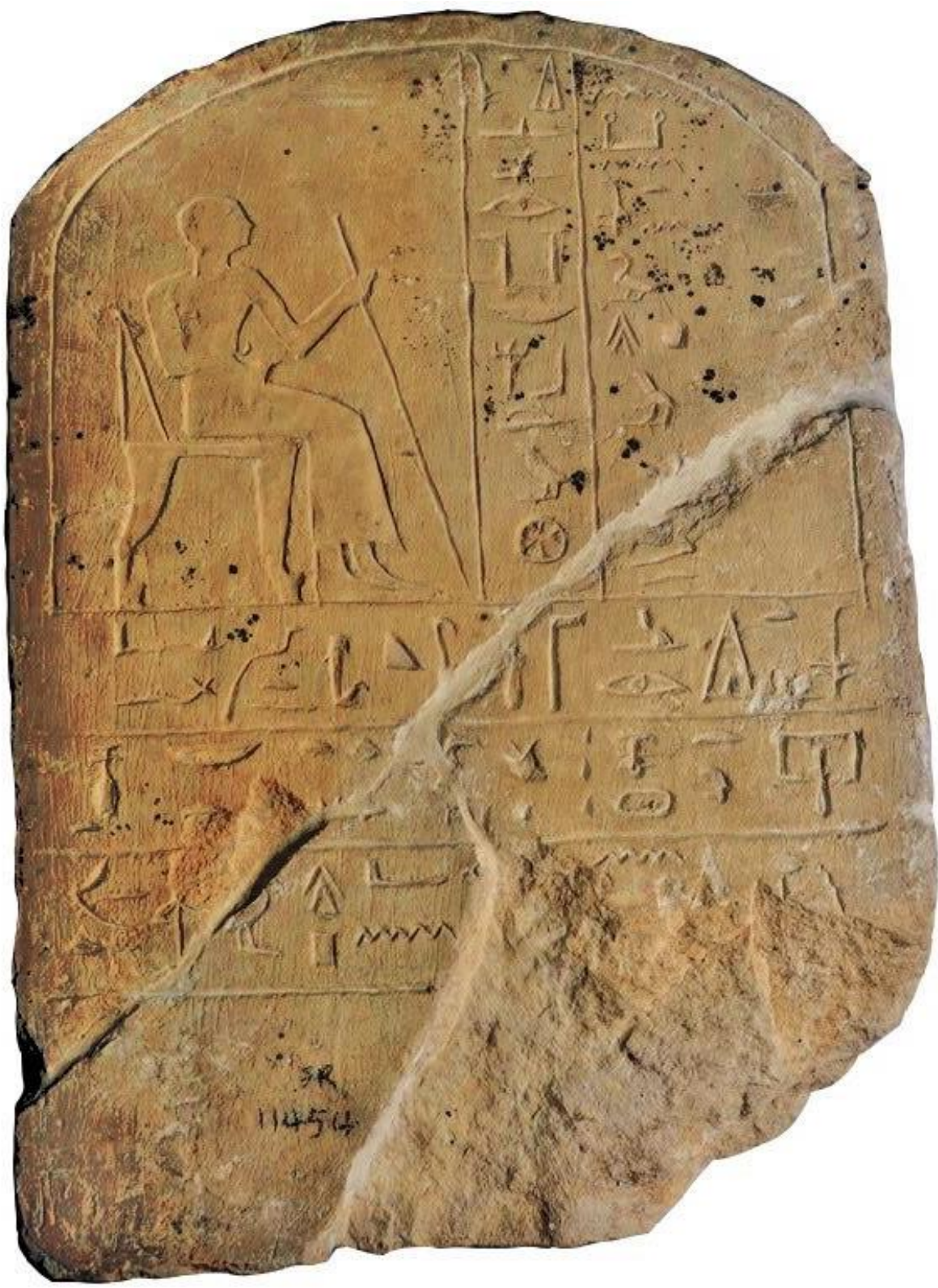

0

PI. I Stela of Hepu, Grand Egyptian Museum, Cairo (GEM 23753/JE 41638)

(Photograph by the author). 


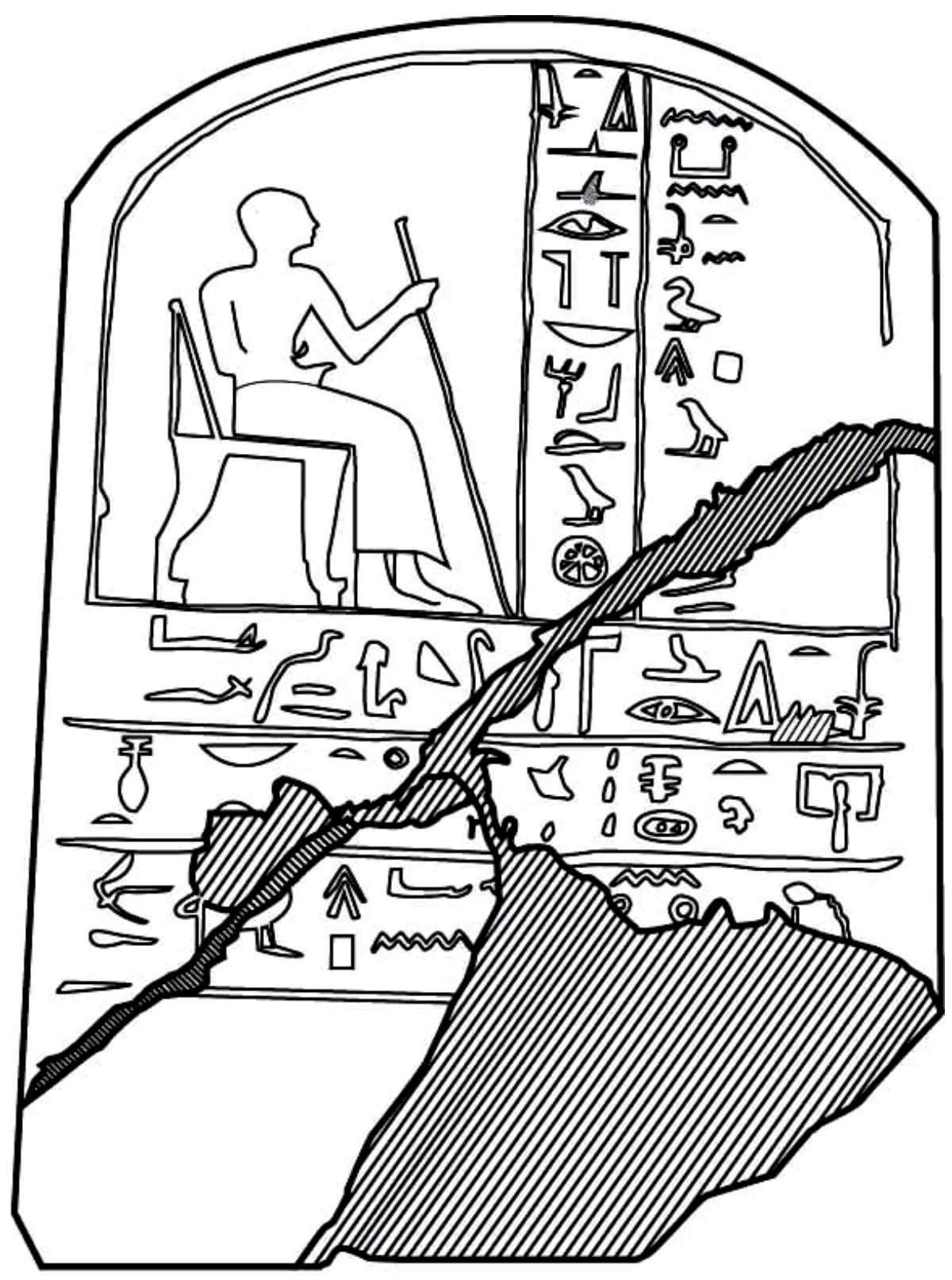

0

Fig. 1. Line drawing of Hepu stela (by Ali Elfiky). 